Supporting Information for

\title{
Compound-specific isotope analysis of human hair: predicting behaviors and biometrics beyond dietary factors
}

Mayara P. V. Matos ${ }^{\mathrm{a}}$ and Glen P. Jackson ${ }^{\mathrm{b}, \mathrm{c}^{*}}$

a Department of Biology, West Virginia University, Morgantown, WV

${ }^{b}$ Department of Forensic and Investigative Science, West Virginia University, Morgantown, WV

${ }^{c}$ C. Eugene Bennett Department of Chemistry, West Virginia University, Morgantown, WV

*Corresponding author: glen.jackson@,mail.wvu.edu

\section{Table of Contents}

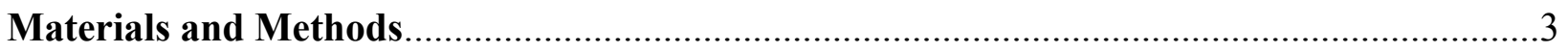

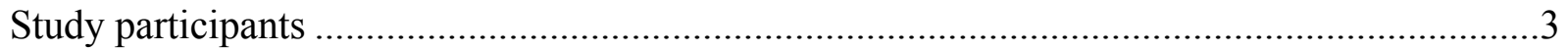

Sample preparation and Instrumental analysis .......................................................

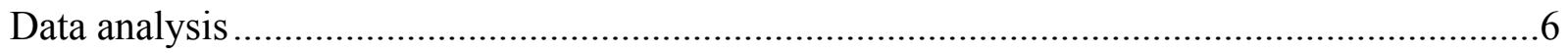

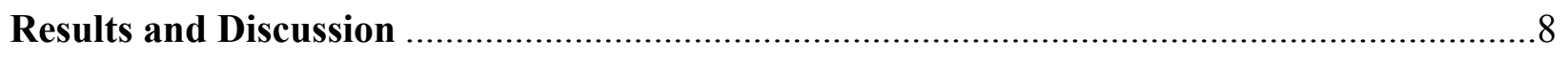

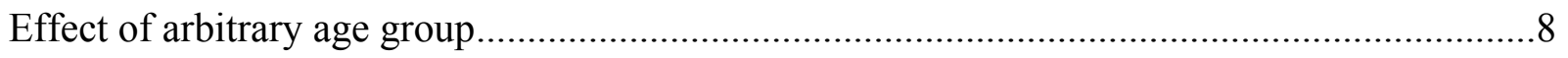

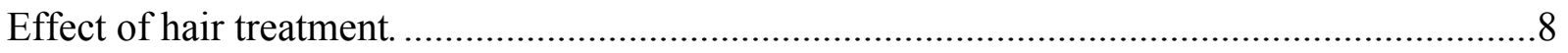

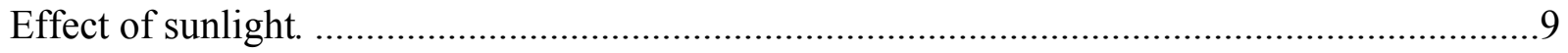

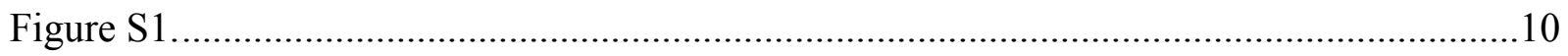

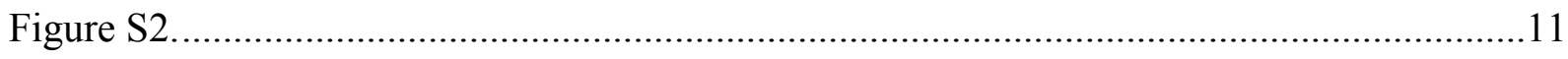

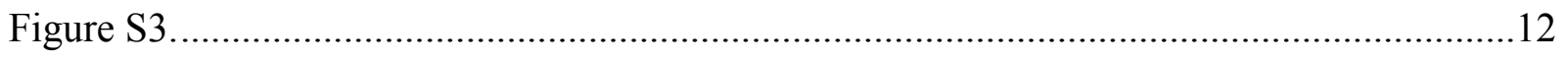

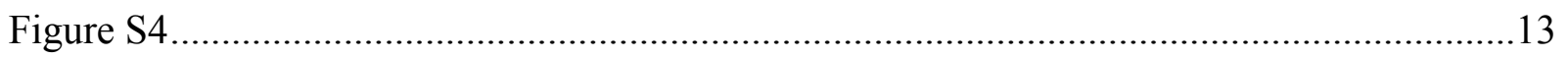

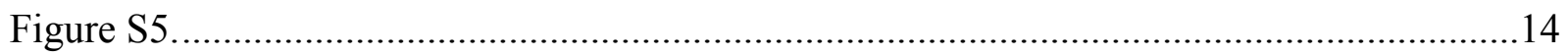

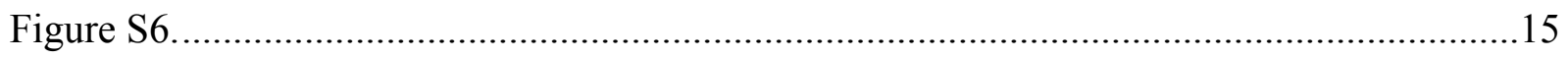

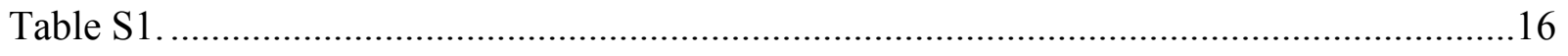

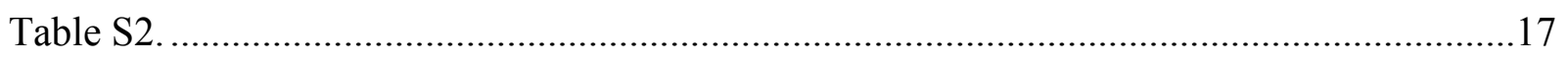

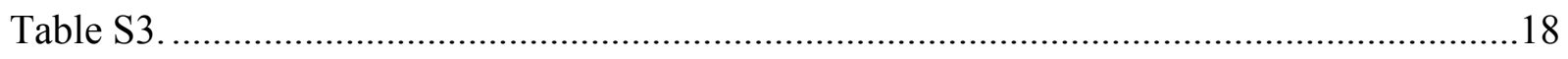

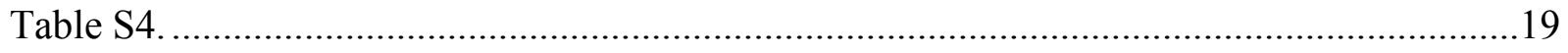

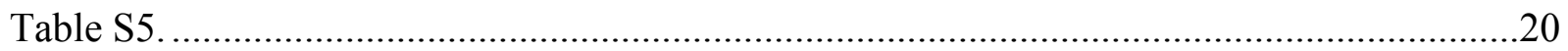


Table S6. 21

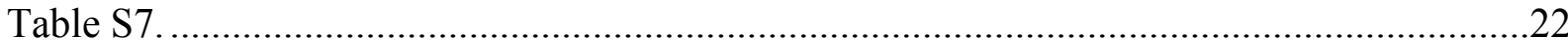

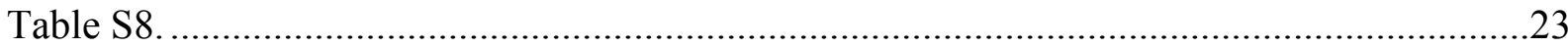

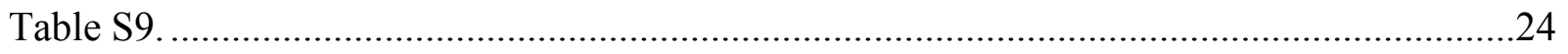

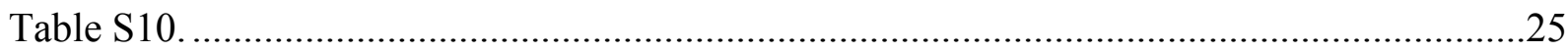

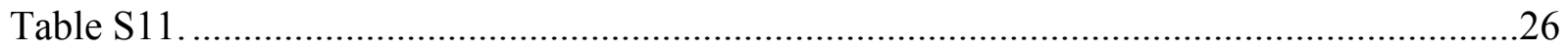

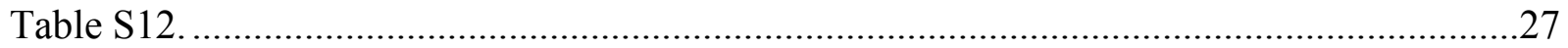

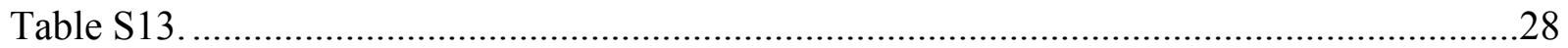

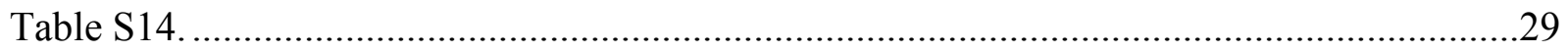

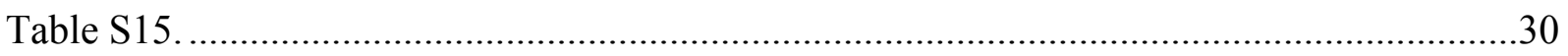

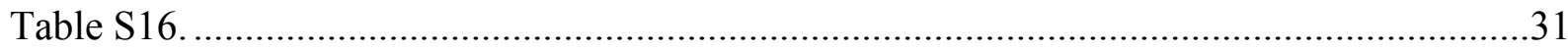

\section{Materials and Methods}

\section{Study participants}

After obtaining an approval from the WVU Institutional Review Board $\left(\mathrm{n}^{\mathrm{o}}\right.$ 1702466936R001), we made a website page specifically to recruit volunteers willing to donate hair samples to this project. We distributed participation requests via a variety of distribution sites, including media blasts, Facebook, word-of-mouth, emails and flyers at conferences. We then mailed each volunteer an envelope containing informed consent forms, project information, instructions on how to collect hair and collection bags, and a questionnaire of approximately 45 questions about their hair treatments, physical health, medical history and diet. Individuals were asked to provide a minimum of $0.1 \mathrm{~g}$ of hair (for example: $>30$ hairs of 24 " length or $>60$ hairs of 12 " length) cut as close as possible to the scalp. We relied on the volunteers to follow these instructions but were unable to reinforce and guarantee that all of them did it. The subjects returned their signed consent forms, hair samples and completed questionnaires in pre-paid return envelopes sent by our group. This sampling method was designed to obtain samples from different states across the US. With this approach, our study obtained samples coming from 22 states within the continental US.

Pregnant, cognitively impaired or incarcerated subjects were not included in this study. Pregnancy is known for affecting isotope balance ${ }^{1-2}$ and would be an extra confounding point 
among the other metabolic factors. We would not be able to access if cognitively impaired individuals fully understood the questionnaire or answered the questions based on their own choice. Finally, the recruitment of incarcerated subjects could lead to legal issues.

\section{Sample preparation and Instrumental analysis}

Hair cleaning. Each hair sample was soaked and vortexed in a solution of methanol: acetone: chloroform (1:1:1) (V:V:V) for 30 minutes, followed by two washings using sonication in deionized water (30 min each). ${ }^{3-5}$ This procedure ensured the removal of external contaminants, such as lipids. Following sonication in deionized water, the samples were dried at $60{ }^{\circ} \mathrm{C}$ for 4 hours. The washed, dried samples of entire length of provided hair strands were pulverized by placing them in a $2 \mathrm{~mL}$ polypropylene tube containing four $3.2 \mathrm{~mm}$ chrome steel beads for 6 min at $3450 \mathrm{rpm}$ in a minibead beater (Biospec Products Inc., Bartlesville, OK, USA). Pulverized samples are more homogenous, easier to weigh precisely in small aliquots and faster to digest, which leads to more reproducible results. ${ }^{6}$

Chemicals. Isotope standards USGS-40, USGS-41, USGS-42 and USGS-43 were purchased from USGS (Reston, VA, USA). Sodium persulfate (99\% purity), Orthophosphoric acid (>85\% purity), sulfuric acid ( $>95 \%$ purity), and amino acids ( $98-99 \%$ purity) and sulfanilamide were purchased from Sigma-Aldrich (St. Louis, MO, USA). Ultra-high purity gases were purchased from Airgas (Morgantown, WV): >99.9999\% He, 99.999\% N2, 99.997\% CO2, and 99.999\% O2.

EA-IRMS. Bulk isotope ratio measurements were performed to investigate $\delta^{13} \mathrm{C}$ and $\delta^{15} \mathrm{~N}$ values. For this analysis, samples of approximately $0.5 \mathrm{mg}$ were weighed in tin capsules and placed in a Thermo Flash HT Plus elemental analyzer (EA) coupled to the Thermo Delta V Advantage isotope ratio mass spectrometer via a Conflo IV interface. All isotopes were measured relative to the respective compressed working gas $\left(\mathrm{CO}_{2}\right.$ and $\left.\mathrm{N}_{2}\right)$. USGS-40 $\left(\delta^{13} \mathrm{C}=-26.39 \%, \delta^{15} \mathrm{~N}=-4.52\right.$ $\%)$ and USGS-41 $\left(\delta^{13} \mathrm{C}=+37.63 \%, \delta^{15} \mathrm{~N}=+47.57 \%\right)$ were used as two-point calibration standards to express the measured isotope values in the international scale against VPDB and air, respectively, using a two-point calibration curve. ${ }^{7}$ Triplicates of USGS-42 $\left(\delta^{13} \mathrm{C}=-21.09 \%\right.$, $\left.\delta^{15} \mathrm{~N}=+8.05 \%\right)$ and USGS-43 $\left(\delta^{13} \mathrm{C}=-21.28 \%, \delta^{15} \mathrm{~N}=+8.44 \%\right)$ were used to ensure the precision of EA measurements was within acceptable $95 \%$ confidence intervals. For quality control of the instrument stability, aliquots of the organic compound sulfanilamide $\left(\mathrm{C}_{6} \mathrm{H}_{8} \mathrm{~N}_{2} \mathrm{O}_{2} \mathrm{~S}\right)$ 
were run in triplicate every after 12 samples. The following equation was used to convert isotope ratios to the delta scale or per mil (\%o). ${ }^{8-9}$

$\delta_{\text {sample }}(\%)=\left(\frac{R \text { sample }}{R \text { standard }}-1\right)$

where the ratio of the heavier over the lighter isotope for sample was defined as $R_{\text {sample }}$, and the abundance ratio of the corresponding international standard as $R_{\text {standard }}$.

LC-IRMS. For CSIA, a $\sim 2 \mathrm{mg}$ aliquot of each pulverized hair sample was hydrolyzed in $6 \mathrm{M}$ hydrochloric acid for $24 \mathrm{~h}$ at $110^{\circ} \mathrm{C}$. The mixture was then filtered using a $0.45 \mu \mathrm{m}$ PTFE syringe filter and evaporated to dryness at $60^{\circ} \mathrm{C}$ under a stream of purified lab air. The obtained dry residue was re-dissolved in $1 \mathrm{~mL}$ deionized water and filtered using a $0.45 \mu \mathrm{m}$ PVDF syringe filter.

Despite being the most common protocol to break peptidic bonds, acid hydrolysis can also be destructive to some AAs. The literature reports the decomposition of tryptophan, histidine, arginine and cysteine, oxidation of methionine, and partial hydrolysis and low recovery of serine and threonine. ${ }^{10-13}$ The $\delta^{13} \mathrm{C}$ values of aspartic acid (Asp) and glutamic acid (Glu) include a contribution from asparagine and glutamine, respectively, which are deaminated to their respective dicarboxylic acids during acid hydrolysis. ${ }^{5,}$ 14-15 Because of deamidation, we reported the peaks for Asp and Glu AAs as Asx and Glx. Importantly, the hydrolysis conditions applied herein do not have a considerable effect on the ${ }^{13} \mathrm{C}$ enrichment, meaning that the $\delta^{13} \mathrm{C}$ values of the recovered amino acids are not affected by acid hydrolysis. 5 , 10, 16-17

For the analysis, we used a Dionex ICS5000 ion chromatography system (ICS) (Dionex, Sunnyvale, CA, USA) coupled through an LC-Isolink interface to a Delta V Plus isotope ratio mass spectrometer (Thermo Fisher Scientific, Bremen, Germany). Chromatographic separation was performed in a Primesep A mixed-mode column $(2.1 \times 250 \mathrm{~mm})$ with a stationary phase particle size of $5 \mu \mathrm{m}$ and pore size of $100 \AA \AA$ (SIELC Technologies, Prospect Heights, IL, USA). The mobile phase initiated with pure deionized water (at least $17.5 \mathrm{M} \Omega$ ) for the first 18.7 minutes, followed by a successive decrease of $\mathrm{pH}$ through a gradient of pure deionized water with $0.03 \mathrm{M}$ sulfuric acid. The flow rate of the mobile phase was $160 \mu \mathrm{L} / \mathrm{min}$, which was the best result of the optimization performed on the method already reported by our group. ${ }^{5}$ Samples of 17 commercially available standard amino acids were analyzed at random intervals throughout 
the sequences as a quality control for the chromatographic separation and overall instrument stability.

Using wet chemical oxidation in the LC-Isolink interface, all the carbon-containing compounds eluting from the HPLC column were quantitatively oxidized to carbon dioxide $\left(\mathrm{CO}_{2}\right)$. Conversion to $\mathrm{CO}_{2}$ occurred in the aqueous phase at $99.9^{\circ} \mathrm{C}$ using sodium persulfate $(100$ $\mathrm{g} / \mathrm{L})$ and phosphoric acid $(1.5 \mathrm{M})$. The resulting $\mathrm{CO}_{2}$ was removed from the cooled solution by a membrane exchanger, and any remaining moisture was removed by two in-line Nafion membrane drying traps before the transfer of the dried $\mathrm{CO}_{2}$ to the IRMS system. Similar procedures using LC system were previously reported. ${ }^{18}$ 


\section{Data analysis}

For both EA and CSIA, Isodat 3.0 (Thermo Scientific, Waltham, MA) was used as the data acquisition software, and IBM SPSS Statistics 25 was used for the statistical analyses. Information collected in the questionnaires provided by each human subject allowed us to group individuals based on different biometric factors. The assumptions of normality, linearity, univariate and multivariate outliers, homogeneity of variance-covariance matrices, homoscedascity and multicollinearity were tested prior to each statistical analysis for compoundspecific data.

Normality of each group was checked by the histograms and QQ-plots of residuals, skewness and kurtosis and Shapiro-Wilk normality test. Even though our total sample size was composed by 82 subjects, the number of subjects in each group changed depending upon which biometric factor was under analysis. We assumed the groups were normally distributed if there was a minimum of 20 subjects per group. ${ }^{19}$ Scatterplots were used to test for linearity. Univariate outliers and multivariate outliers were accessed via comparison of mean and 5\% trimmed mean, box and whiskers plots and Mahalanobis distance, respectively. Homogeneity of variancecovariance matrices was tested using Box's test and when the results violated the test, we checked the more robust test Pillai's trace. This test also indicates if the linear combination of dependent variables generates any statistically significant difference among the tested groups. For multicollinearity, we analyzed if any of the variables showed correlation around 0.9 in the correlation matrix, which would be a reason for concern. In addition, we also checked values of Tolerance and Variance inflation factor (VIF) to ensure no multicollinearity was interfering in the results. The Levene's test for homoscedascity (equality) of variances was also performed before multivariate analysis of variance (MANOVA). If this assumption was violated, we performed the more robust Welch's test on the variables under question.

According to the assumptions testing results, an appropriate parametric or nonparametric test was performed. In this study we used One-way ANOVA or MANOVA followed by Tukey HSD or Games-Howell test, independent t-test (Student's t-test), linear regression and linear discriminant analysis. Mann-Whitney U test, and Kruskal-Wallis test followed by Dunn's post hoc test were performed as nonparametric alternatives when samples were dichotomous or had three or more groups, respectively. Pearson correlation coefficient was used when the biometric 
factor was a continuous variable or had groups with $>20$ subjects (e.g. sex). Factors (e.g. age) in binned categories were tested via Spearman's rho correlation. The strength of the correlation relationship was interpreted according to the guidelines proposed by Cohen. ${ }^{20} \mathrm{~A}$ single factor ANOVA test was performed to test the null hypothesis that each $\delta^{13} \mathrm{C}$ value or quantity of AA has no significant difference between groups using a same fixed factor (e.g. one of the biometric factors). Furthermore, MANOVA was used to test the same hypothesis but using more than one dependent variable at once. Furthermore, independent samples t-test (Student's t-test) and posthoc pairwise comparisons (e.g. Tukey's HSD test or Games-Howell test) reduced the frequency of type 1 errors by comparing the mean isotope ratios for individual groups when equal variances were assumed or not assumed, respectively. In both cases we applied an extra layer of correction to reduce type 1 errors via a Bonferroni adjustment. A cut-off significance value $\alpha=0.05$ was used for all statistical tests, unless otherwise mentioned. A descriptive analysis with standard statistical parameters (number of samples, mean or median, standard deviation, standard error, $95 \%$ confidence interval) was also performed.

In prior research from our group, ANOVA of bulk isotope ratios of $\delta^{13} \mathrm{C}$ and $\delta^{15} \mathrm{~N}$ values performed on 20 female Jordanian subjects indicated that isotope ratios could, to some extent, be used to differentiate hair of individuals. ${ }^{5}$ Similarly, the same statistical tests were performed for CSIA. Single factor ANOVA was used to determine significant differences for an amino acidwhich is a unique factor-whereas multiple factor ANOVA presented interactions between the different groups of organisms (various factors). MANOVA tested for interactions between the diverse response variables (amino acids). Also, linear discriminant analysis (LDA) using original discriminant rules and leave-one-out cross-validation (LOOCV) were applied to classify subjects into prior groups more accurately. 


\section{Results and Discussion}

Effect of arbitrary age group. None of the AA quantities were statistically different across the three arbitrary age groups at 95\% significance level in the Kruskal-Wallis test, but some of them were significant at the $90 \%$ level. After a Dunn's post hoc test followed by Bonferroni adjustment, $\operatorname{Ser}_{\mathrm{q}}$ and $\mathrm{Gly}_{\mathrm{q}}$ were statistically different between the age groups $\leq 25$ and $\geq 46$ years old $(P=0.065$ and $P=0.069)$. The difference in the medians was very small $(3-5 \%)$ : For $\operatorname{Ser}_{\mathrm{q}}$, the median relative quantities were 3.91 for the $\leq 25$ years-old group and 4.1 for the $\geq 46$ yearsold group. For $\mathrm{Gly}_{\mathrm{q}}$, the median values for the $<25$-year-old and $\geq 46$-year-old were 2.1 and 2.2, respectively. The variable $\mathrm{Asx}_{\mathrm{q}}$ was significantly different between the age groups $\leq 25$ and $\geq 46$ only at the $83 \%$ significance level $(P=0.17)$, showing medians of 2.03 relative mols for the younger group compared to 2.01 relative mols for the older one. The variable $\mathrm{Xle}_{\mathrm{q}}$ was not able to discriminate between age groups up to the tested alpha level. Attempts to classify individuals into age groups was not very successful, reaching only $42.7 \%$ of cases after LOOCV due to the very low Eigenvalues associated with the two canonical functions $(<0.3)$.

Effect of hair treatment. Twenty-six of the 101 total subjects reported doing one of the following hair treatments: bleaching (5), chemical straightening (1), or coloring (25). All individuals were females. Subjects who bleached their hair also did coloring, but the opposite was not true. None of the participants reported doing baldness or Perm treatments. The two selfreported vegans also colored their hair. Table S13 shows that different hair treatments were not significantly different among themselves in the bulk isotope values $(P=0.141$ and $P=0.876$ for bulk $\delta^{13} \mathrm{C}$ and $\delta^{15} \mathrm{~N}$, respectively). There was also no statistical difference between females who bleached/died their hair and the ones who did not $\left(P=0.912\right.$ and $P=0.173$ for bulk $\delta^{13} \mathrm{C}$ and $\delta^{15} \mathrm{~N}$, respectively) (Table S14), indicating the bulk values were unaffected by these treatments.

We also tested the population of females for any of the AA isotope variables that could have been affected by a hair treatment. We observed no statistical difference between the groups with $(n=20)$ or without $(n=37)$ hair treatment (Table S15). However, at the AA composition level, the original quantity of Gly in hair was the only AA statistically different between those group $(P=0.028)$ (Table S16). Cosmetic procedures in hair (chemical bleaching, alkaline 
straighteners, hair dyes, etc) can alter both $\mathrm{C} / \mathrm{N}$ ratios and isotope values because these processes often cause fragmentation of proteins and conversion of AAs to derivatives. ${ }^{21-23}$ Cysteine is usually cited as the most affected AA, but we did not observe the same in our results because the Met/Cyt variable did not meet the multicollinearity assumptions.

Effect of sunlight. We questioned the subjects about their typical sunlight exposure per day. We divided the answers into four groups: ">2 h/day", "1-2 h/day", " $<1$ h/day" and "almost never". In the original dataset, we observed significant correlations between the $\delta^{13} \mathrm{C}$ values of $\operatorname{Tyr}(r=$ $0.252, P<0.05)$ and Lys $(r=-0.335, P<0.01)$. After controlling for sex and diet, the correlations changed to $r=0.324(P<0.01)$ for Tyr and $r=-0.252(P<0.05)$ for Lys. New correlations also appeared for the $\delta^{13} \mathrm{C}$ values of $\operatorname{Ser}(r=-0.248, P<0.05)$ and $\operatorname{Arg}(r=0.271, P$ $<0.05)$. Interestingly, the $\delta^{13} \mathrm{C}$ values of Xle, Lys and His showed a significant difference across the four groups in Kruskal-Wallis test at the 95\% CI, while Ser and Tyr were significant at the $90 \%$ CI. However, there was no clear pattern of ${ }^{13} \mathrm{C}$ enrichment in these AAs, suggesting that the statistical significance was probably not attributed to sunlight exposure.

Regarding the AAs quantities, the only significant correlation was for $\mathrm{Phe}_{\mathrm{q}}(r=-0.304, P<$ 0.01). After correction for sex, the correlation was kept significant $(r=-0.294, P<0.01)$.

Overall, the number of Phe molecules in the scalp hair of the subjects was very small $(<1 \mathrm{~mol})$. This result was expected because ultraviolet radiation from sunlight exposure degrades aromatic AAs via photo-degradation, ${ }^{23-24}$ and most American individuals do not cover their heads when outdoors. It also supports the findings from Rashaid et al., ${ }^{25}$ where hair of Jordanian females showed high abundance of Phe because the wearing of hijab avoided Phe degradation. LDA showed that $54 \%$ and $46 \%$ of the subjects were correctly classified into the sunlight exposure after LOOCV for isotope variables and quantities of AAs, respectively. These values beat the random guessing probability of $25 \%$ but are still not enough for proper discrimination. 

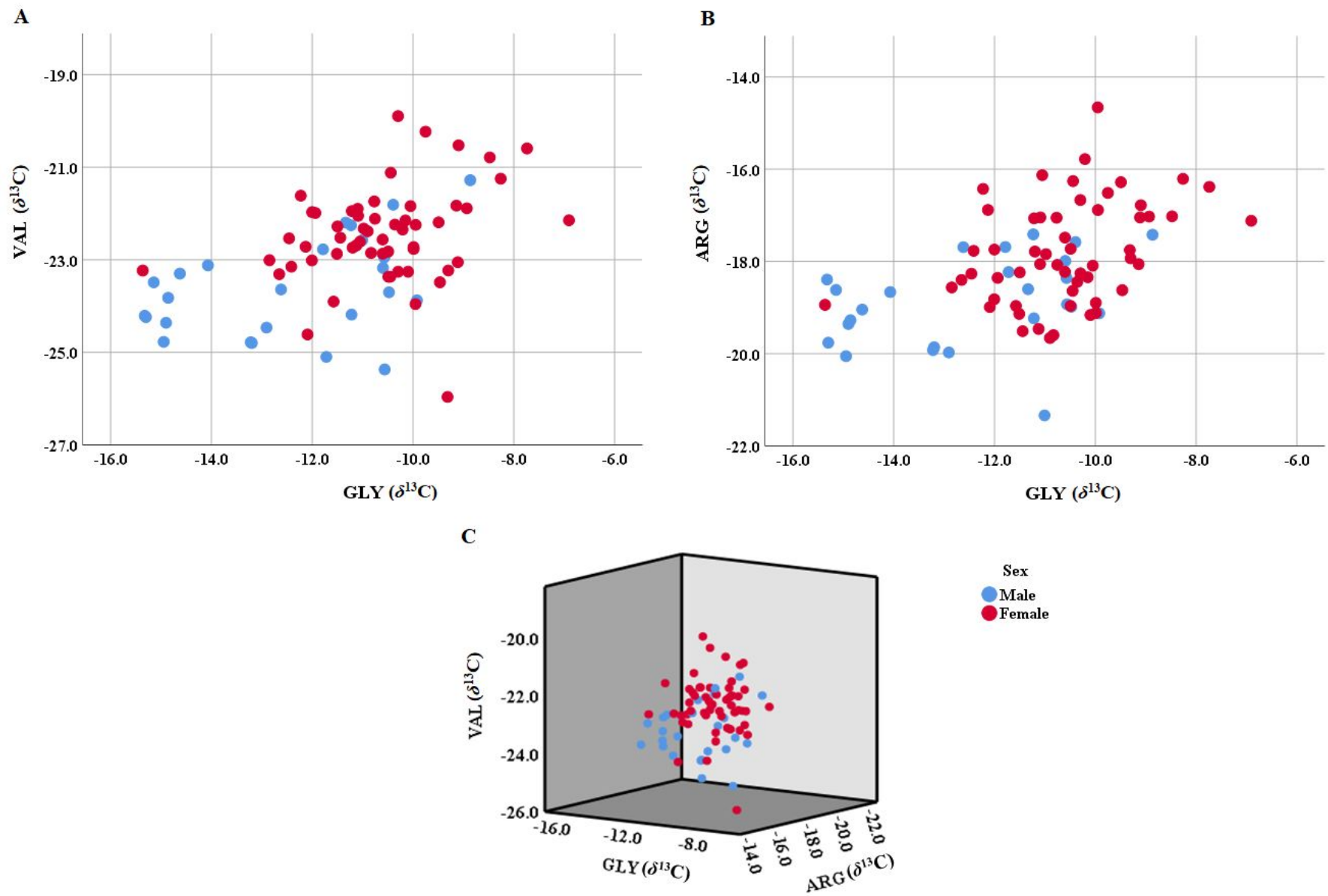

Figure S1. Bivariate plot of the $\delta^{13} \mathrm{C}$ of the amino acids with the highest $F$ values in MANOVA test using SEX as independent variable.

A) $\delta^{13} \mathrm{C}$ values of Gly and $\mathrm{Val}(F=22.119$ and $F=20.873$, respectively), and $\mathbf{B}) \delta^{13} \mathrm{C}$ values of Gly and $\operatorname{Arg}(F=16.829)$. C) 3D scatterplot of the carbon isotope values from the three amino acids with the most significant influence on the classification based on sex. 


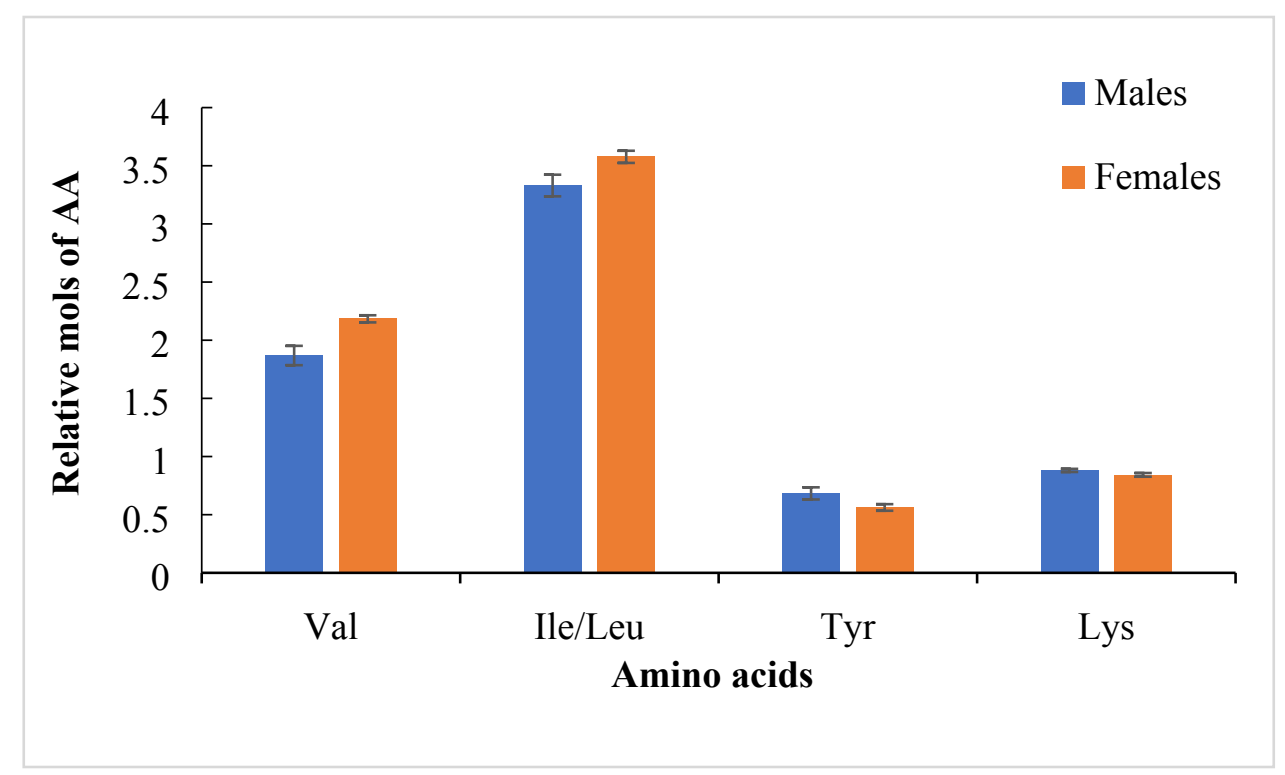

Figure S2. Relative amino acid composition in the hair of males and female subjects. Val was more abundant in females, showing an average of $2.18 \pm 0.03$ and $1.86 \pm 0.08$ for males. Xle showed the same pattern, having an average of $3.57 \pm 0.05$ for females and $3.33 \pm 0.09$ for males. Tyr and Lys presented the opposite trend, being more abundant in males $(0.68 \pm 0.05$ and $0.88 \pm 0.01$, respectively) than in females $(0.56 \pm 0.03$ and $0.84 \pm 0.02)$. Values are expressed as mean $\pm 95 \%$ confidence interval of the mean. 
A

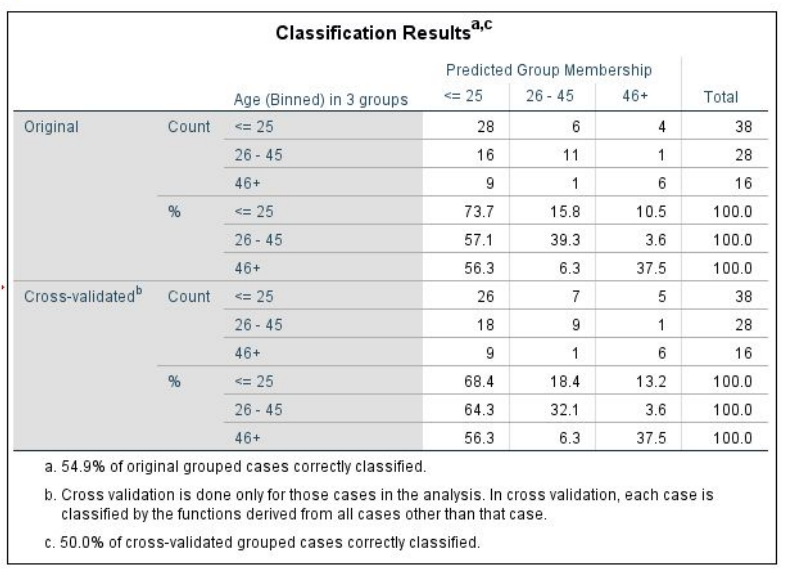

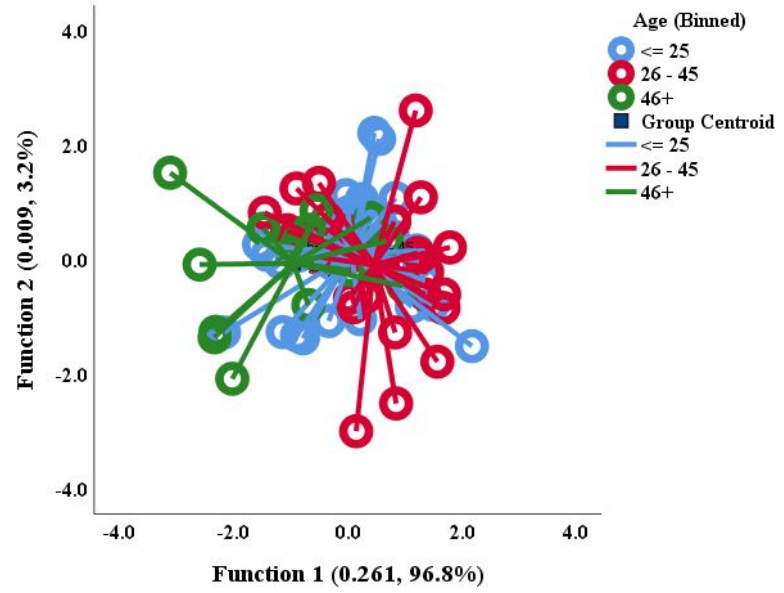

Figure S3. A) LDA results using AGE as the classification factor and $\delta^{13} \mathrm{C}$ values of three amino acids after data was corrected for diet and sex. We obtained approximately $50 \%$ of correct classification after LOOCV. B) LDA plots for 82 subjects using isotope ratios of Met/Cyt, Xle and Lys. The variables were chosen based on their higher canonical discriminant functions compared to the other amino acids. The two discriminant functions have very small Eigenvalues $(<1)$, which is the possible reason for the poor classification. 

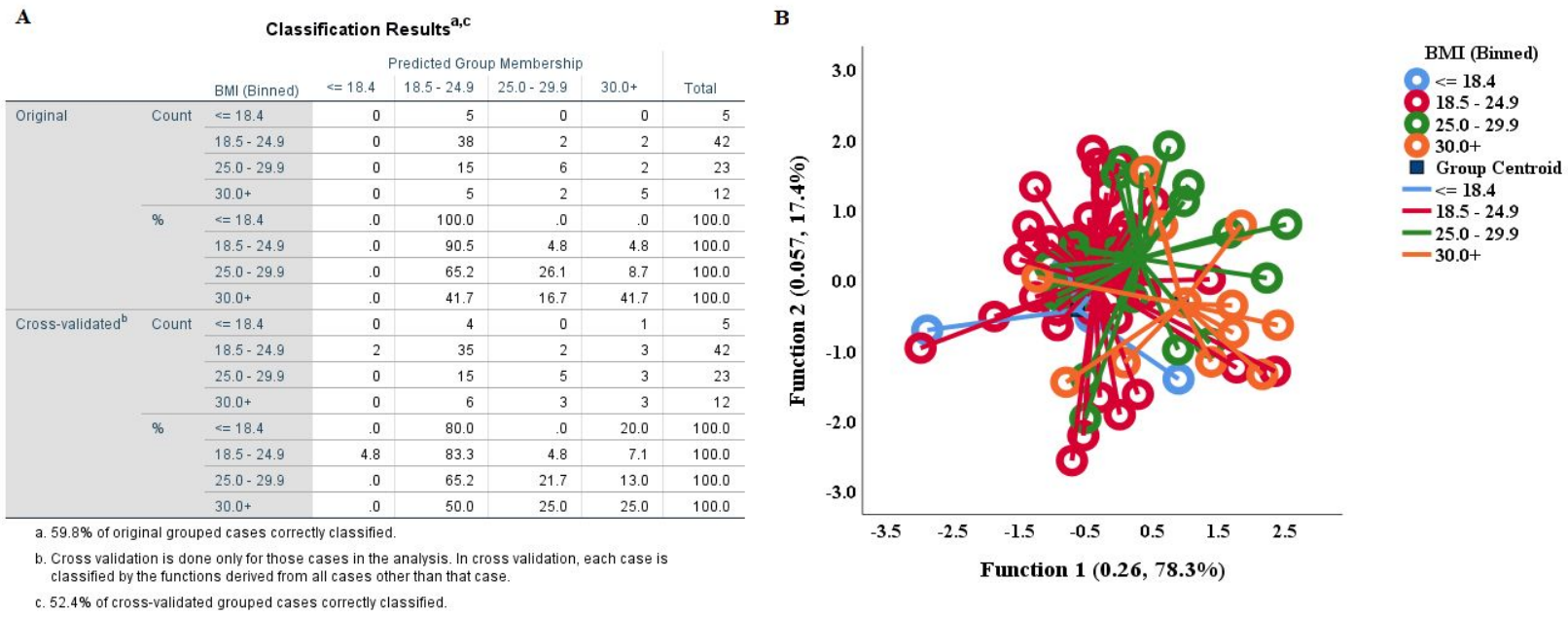

Figure S4. A) LDA results using BMI as classification factor and relative quantities in mols of six AA variables. Leave one-out cross-validation reached just $50 \%$ of accuracy in discriminating the cases into the BMI groups. B) LDA plots for 82 subjects using Asx ${ }_{\mathrm{q}}, \mathrm{Gly}_{\mathrm{q}}, \mathrm{Xle}_{\mathrm{q}}, \mathrm{Tyr}_{\mathrm{q}}, \mathrm{Lys}_{\mathrm{q}}$ and $\operatorname{Arg}_{\mathrm{q}}$ as predictor variables. The variables were chosen based on their higher canonical discriminant functions compared to the other quantities of AA. Eigenvalues were very small $(<1)$ and not helpful in the classification. 


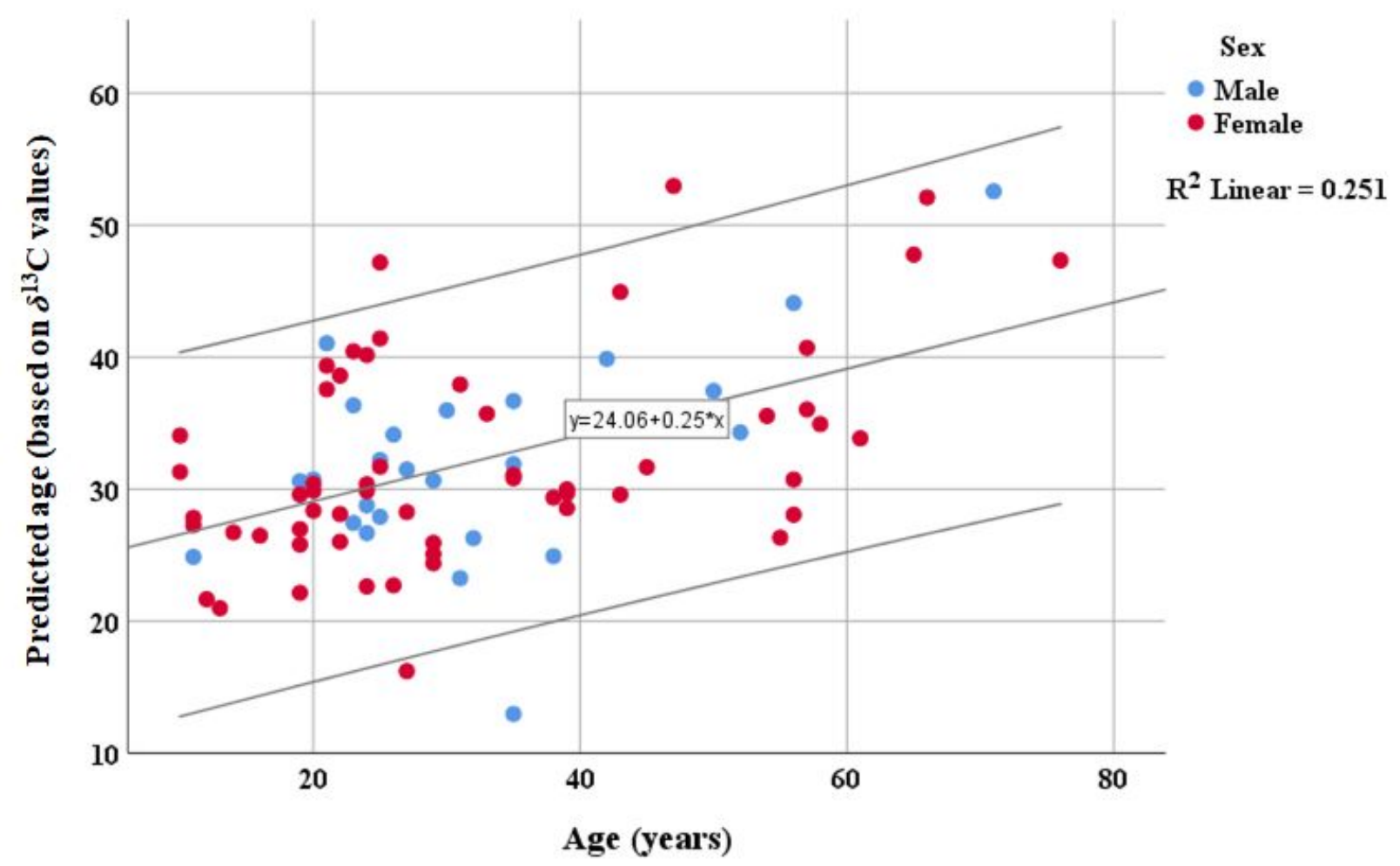

Figure S5. Correlation between age and predicted age using a general linear model based on the $\delta^{13} \mathrm{C}$ values of six amino acids (Asx, Val, Xle, Lys and Arg). This model explained only 25\% of the variance in age. The upper and lower lines show the $95 \%$ CI for individual predictions. 


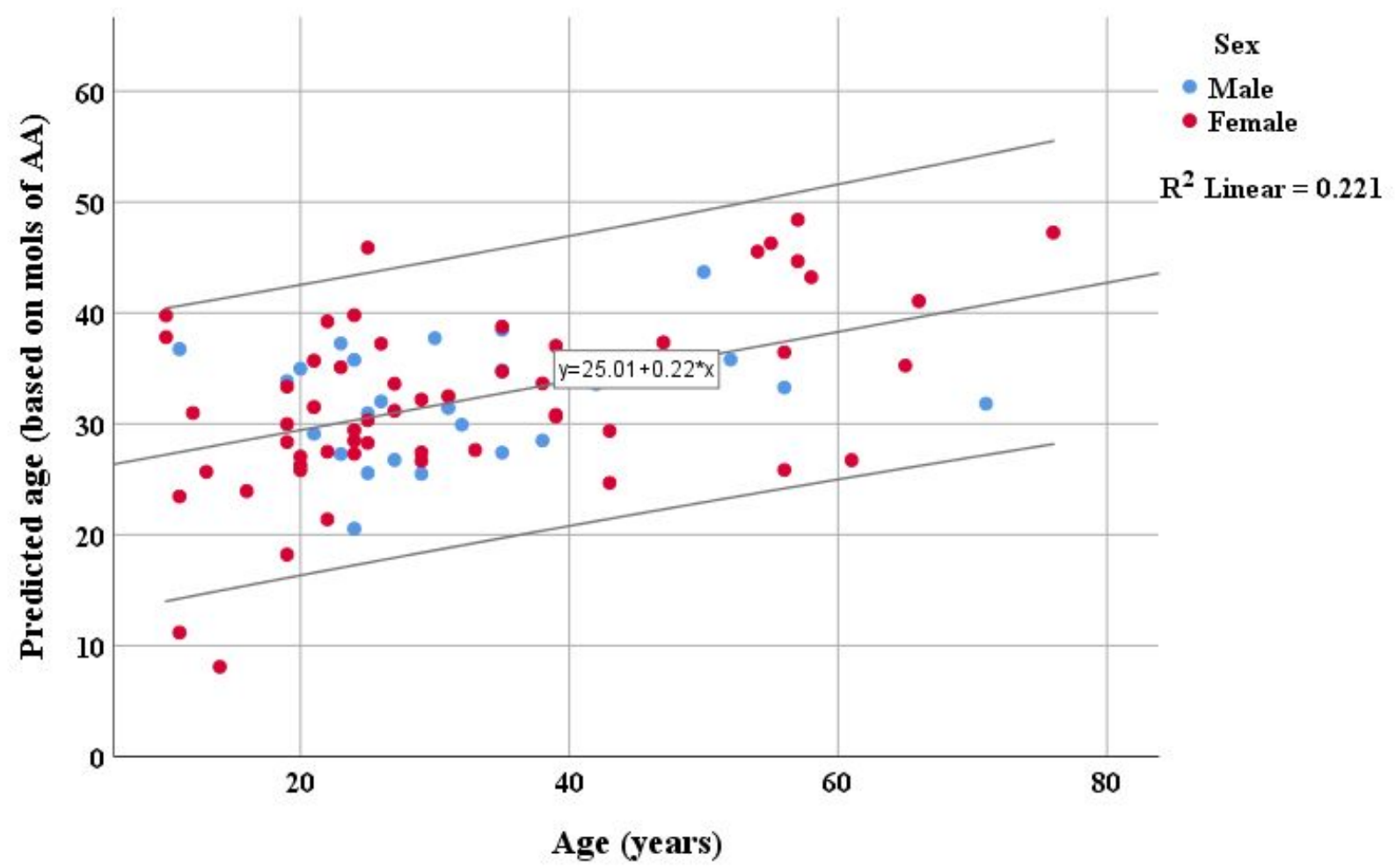

Figure S6. Age prediction based on the relative molar quantities of five AA variables $\left(\mathrm{Asx}_{\mathrm{q}}\right.$, $\mathrm{Ser}_{\mathrm{q}}, \mathrm{Gly}_{\mathrm{q}}, \mathrm{Xle}_{\mathrm{q}}$, and $\mathrm{Tyr}_{\mathrm{q}}$ ). This general linear regression model explained only $22 \%$ of the variance in age. The error bars show the $95 \%$ CI for individual predictions. Intercept for the model was not significant when using $\alpha=0.05(P=0.058)$. 
Table S1. Pearson product-moment correlation coefficient among the $\delta^{13} \mathrm{C}$ values of 13 amino acids (11 variables). The correlations ranged from $r=0.226$ to $r=0.707$. * indicates correlation was significant at the 0.05 level (2-tailed), ${ }^{* *}$ correlation was significant at the 0.01 level (2tailed). $n=82$.

\begin{tabular}{|c|c|c|c|c|c|c|c|c|c|c|c|c|}
\hline & & ASX & SER & GLY & VAL & $\begin{array}{l}\text { MET/ } \\
\text { CYT }\end{array}$ & XLE & TYR & LYS & HIS & PHE & ARG \\
\hline \multirow[t]{2}{*}{ ASX } & Pearson Correlation & 1 & $.499^{* *}$ & $.363^{* *}$ & $.409^{* *}$ & $.465^{* *}$ & $.454^{* *}$ & $.365^{* *}$ & .159 & .160 & .170 & $.496^{* *}$ \\
\hline & Sig. (2-tailed) & & .000 & .001 & .000 & .000 & .000 & .001 & .155 & .150 & .127 & .000 \\
\hline \multirow[t]{2}{*}{ SER } & Pearson Correlation & $.499^{* *}$ & 1 & $.494^{* *}$ & $.541^{* *}$ & $.587^{* *}$ & $.655^{* *}$ & .120 & $.314^{* *}$ & .188 & .139 & $.537^{* *}$ \\
\hline & Sig. (2-tailed) & .000 & & .000 & .000 & .000 & .000 & .283 & .004 & .091 & .213 & .000 \\
\hline \multirow[t]{2}{*}{ GLY } & Pearson Correlation & $.363^{* *}$ & $.494^{* *}$ & 1 & $.560^{* *}$ & $.326^{* *}$ & $.310^{* *}$ & $.374^{* *}$ & .084 & $.254^{*}$ & -.106 & $.554^{* *}$ \\
\hline & Sig. (2-tailed) & .001 & .000 & & .000 & .003 & .005 & .001 & .456 & .021 & .341 & .000 \\
\hline \multirow[t]{2}{*}{ VAL } & Pearson Correlation & $.409^{* *}$ & $.541^{* *}$ & $.560^{* *}$ & 1 & $.314^{* *}$ & $.705^{* *}$ & $.555^{* *}$ & $.226^{*}$ & $.540^{* *}$ & .107 & $.707^{* *}$ \\
\hline & Sig. (2-tailed) & .000 & .000 & .000 & & .004 & .000 & .000 & .041 & .000 & .340 & .000 \\
\hline MET/ & Pearson Correlation & $.465^{* *}$ & $.587^{* *}$ & $.326^{* *}$ & $.314^{* *}$ & 1 & $.570^{* *}$ & $.333^{* *}$ & $.292^{* *}$ & .082 & $.237^{*}$ & $.458^{* *}$ \\
\hline CYT & Sig. (2-tailed) & .000 & .000 & .003 & .004 & & .000 & .002 & .008 & .462 & .032 & .000 \\
\hline \multirow[t]{2}{*}{ XLE } & Pearson Correlation & $.454^{* *}$ & $.655^{* *}$ & $.310^{* *}$ & $.705^{* *}$ & $.570^{* *}$ & 1 & $.447^{* *}$ & $.398^{* *}$ & $.327^{* *}$ & $.326^{* *}$ & $.604^{* *}$ \\
\hline & Sig. (2-tailed) & .000 & .000 & .005 & .000 & .000 & & .000 & .000 & .003 & .003 & .000 \\
\hline \multirow[t]{2}{*}{ TYR } & Pearson Correlation & $.365^{* *}$ & .120 & $.374^{* *}$ & $.555^{* *}$ & $.333^{* *}$ & $.447^{* *}$ & 1 & .006 & $.358^{* *}$ & .015 & $.661^{* *}$ \\
\hline & Sig. (2-tailed) & .001 & .283 & .001 & .000 & .002 & .000 & & .960 & .001 & .896 & .000 \\
\hline \multirow[t]{2}{*}{ LYS } & Pearson Correlation & .159 & $.314^{* *}$ & .084 & $.226^{*}$ & $.292^{* *}$ & $.398^{* *}$ & .006 & 1 & -.086 & $.361^{* *}$ & .101 \\
\hline & Sig. (2-tailed) & .155 & .004 & .456 & .041 & .008 & .000 & .960 & & .443 & .001 & .369 \\
\hline \multirow[t]{2}{*}{ HIS } & Pearson Correlation & .160 & .188 & $.254^{*}$ & $.540^{* *}$ & .082 & $.327^{* *}$ & $.358^{* *}$ & -.086 & 1 & .122 & $.488^{* *}$ \\
\hline & Sig. (2-tailed) & .150 & .091 & .021 & .000 & .462 & .003 & .001 & .443 & & .273 & .000 \\
\hline \multirow[t]{2}{*}{ PHE } & Pearson Correlation & .170 & .139 & -.106 & .107 & $.237^{*}$ & $.326^{* *}$ & .015 & $.361^{* *}$ & .122 & 1 & .176 \\
\hline & Sig. (2-tailed) & .127 & .213 & .341 & .340 & .032 & .003 & .896 & .001 & .273 & & .114 \\
\hline \multirow[t]{2}{*}{ ARG } & Pearson Correlation & $.496^{* *}$ & $.537^{* *}$ & $.554^{* *}$ & $.707^{* *}$ & $.458^{* *}$ & $.604^{* *}$ & $.661^{* *}$ & .101 & $.488^{* *}$ & .176 & 1 \\
\hline & Sig. (2-tailed) & .000 & .000 & .000 & .000 & .000 & .000 & .000 & .369 & .000 & .114 & \\
\hline
\end{tabular}


Table S2. Pearson product-moment correlation coefficient among the quantities of 13 amino acids (11 variables). The correlations ranged from $r=-0.241$ to $r=0.826 . *$ indicates correlation was significant at the 0.05 level (2-tailed), ${ }^{* *}$ correlation was significant at the 0.01 level (2tailed). $n=82$.

\begin{tabular}{|c|c|c|c|c|c|c|c|c|c|c|c|c|}
\hline & & $\operatorname{ASX}_{\mathrm{q}}$ & $\mathrm{SER}_{\mathrm{q}}$ & $\mathrm{GLY}_{\mathrm{q}}$ & $\mathrm{VAL}_{\mathrm{q}}$ & $\begin{array}{l}\text { MET/ } \\
\mathrm{CYT}_{\mathrm{q}} \\
\end{array}$ & $\mathrm{XLE}_{\mathrm{q}}$ & $\mathrm{TYR}_{\mathrm{q}}$ & $\mathrm{LYS}_{\mathrm{q}}$ & $\mathrm{HIS}_{\mathrm{q}}$ & $\mathrm{PHE}_{\mathrm{q}}$ & $\mathrm{ARG}_{\mathrm{q}}$ \\
\hline \multirow[t]{2}{*}{$\mathrm{ASX}_{\mathrm{q}}$} & Pearson Correlation & 1 & -.066 & -.109 & .104 & $-.776^{* *}$ & $.369^{* *}$ & -.023 & -.009 & $-.351^{* *}$ & $.260^{*}$ & $.476^{* *}$ \\
\hline & Sig. (2-tailed) & & .558 & .331 & .353 & .000 & .001 & .834 & .936 & .001 & .018 & .000 \\
\hline \multirow[t]{2}{*}{$\mathrm{SER}_{\mathrm{q}}$} & Pearson Correlation & -.066 & 1 & $.356^{* *}$ & $-.545^{* *}$ & .079 & $-.615^{* *}$ & $.285^{* *}$ & .067 & .079 & -.063 & .129 \\
\hline & Sig. (2-tailed) & .558 & & .001 & .000 & .481 & .000 & .009 & .547 & .481 & .573 & .248 \\
\hline \multirow[t]{2}{*}{$\mathrm{GLY}_{\mathrm{q}}$} & Pearson Correlation & -.109 & $.356^{* *}$ & 1 & -.024 & .009 & -.186 & -.001 & .026 & -.114 & -.179 & -.187 \\
\hline & Sig. (2-tailed) & .331 & .001 & & .832 & .933 & .095 & .991 & .816 & .307 & .108 & .092 \\
\hline \multirow[t]{2}{*}{$\mathrm{VAL}_{\mathrm{q}}$} & Pearson Correlation & .104 & $-.545^{* *}$ & -.024 & 1 & $-.408^{* *}$ & $.826^{* *}$ & $-.729^{* *}$ & -.203 & $-.311^{* *}$ & -.180 & -.109 \\
\hline & Sig. (2-tailed) & .353 & .000 & .832 & & .000 & .000 & .000 & .068 & .004 & .106 & .332 \\
\hline \multirow[t]{2}{*}{$\mathrm{MET} / \mathrm{CYT}_{\mathrm{q}}$} & Pearson Correlation & $-.776^{* *}$ & .079 & .009 & $-.408^{* *}$ & 1 & $-.523^{* *}$ & .147 & -.033 & $.287^{* *}$ & $-.269^{*}$ & $-.492^{* *}$ \\
\hline & Sig. (2-tailed) & .000 & .481 & .933 & .000 & & .000 & .188 & .772 & .009 & .015 & .000 \\
\hline \multirow[t]{2}{*}{$\mathrm{XLE}_{\mathrm{q}}$} & Pearson Correlation & $.369^{* *}$ & $-.615^{* *}$ & -.186 & $.826^{* *}$ & $-.523^{* *}$ & 1 & $-.662^{* *}$ & $-.241^{*}$ & $-.391^{* *}$ & -.090 & -.066 \\
\hline & Sig. (2-tailed) & .001 & .000 & .095 & .000 & .000 & & .000 & .029 & .000 & .420 & .557 \\
\hline \multirow[t]{2}{*}{$\mathrm{TYR}_{\mathrm{q}}$} & Pearson Correlation & -.023 & $.285^{* *}$ & -.001 & $-.729^{* *}$ & .147 & $-.662^{* *}$ & 1 & -.078 & .176 & -.050 & .153 \\
\hline & Sig. (2-tailed) & .834 & .009 & .991 & .000 & .188 & .000 & & .488 & .114 & .655 & .169 \\
\hline \multirow[t]{2}{*}{$\mathrm{LYS}_{\mathrm{q}}$} & Pearson Correlation & -.009 & .067 & .026 & -.203 & -.033 & $-.241^{*}$ & -.078 & 1 & $.323^{* *}$ & $.666^{* *}$ & -.156 \\
\hline & Sig. (2-tailed) & .936 & .547 & .816 & .068 & .772 & .029 & .488 & & .003 & .000 & .162 \\
\hline \multirow[t]{2}{*}{$\mathrm{HIS}_{\mathrm{q}}$} & Pearson Correlation & $-.351^{* *}$ & .079 & -.114 & $-.311^{* *}$ & $.287^{* *}$ & $-.391^{* *}$ & .176 & $.323^{* *}$ & 1 & .188 & -.196 \\
\hline & Sig. (2-tailed) & .001 & .481 & .307 & .004 & .009 & .000 & .114 & .003 & & .090 & .077 \\
\hline \multirow[t]{2}{*}{$\mathrm{PHE}_{\mathrm{q}}$} & Pearson Correlation & $.260^{*}$ & -.063 & -.179 & -.180 & $-.269^{*}$ & -.090 & -.050 & $.666^{* *}$ & .188 & 1 & .079 \\
\hline & Sig. (2-tailed) & .018 & .573 & .108 & .106 & .015 & .420 & .655 & .000 & .090 & & .482 \\
\hline \multirow[t]{2}{*}{$\mathrm{ARG}_{\mathrm{q}}$} & Pearson Correlation & $.476^{* *}$ & .129 & -.187 & -.109 & $-.492^{* *}$ & -.066 & .153 & -.156 & -.196 & .079 & 1 \\
\hline & Sig. (2-tailed) & .000 & .248 & .092 & .332 & .000 & .557 & .169 & .162 & .077 & .482 & \\
\hline
\end{tabular}


Table S3. Person product-moment correlation coefficient for SEX factor vs. $\delta^{13} \mathrm{C}$ values of 13 amino acids (11 variables). The strength of correlation and significance increased when the data was corrected for diet. * indicates correlation was significant at the 0.05 level (2-tailed), ** correlation was significant at the 0.01 level (2-tailed). $n=82$ for original data and all diet corrections, except bulk diet correction $(n=81)$.

\begin{tabular}{|c|c|c|c|c|c|}
\hline Amino acid & $\begin{array}{l}\text { Correlation } \\
\text { coefficient }\end{array}$ & $\begin{array}{c}\text { Original } \\
\delta^{13} \mathrm{C} \\
\text { dataset }\end{array}$ & $\begin{array}{c}\text { Diet correction for } \\
\text { meat intake }\end{array}$ & $\begin{array}{c}\text { Weighted diet } \\
\text { correction }\end{array}$ & $\begin{array}{l}\text { Bulk diet } \\
\text { correction }\end{array}$ \\
\hline & & Sex & Sex & Sex & Sex \\
\hline \multirow[t]{2}{*}{ ASX } & $\begin{array}{c}\text { Pearson } \\
\text { Correlation }\end{array}$ & -0.132 & -0.097 & -0.183 & 0.021 \\
\hline & Sig. (2-tailed) & 0.237 & 0.385 & 0.100 & 0.850 \\
\hline \multirow[t]{2}{*}{ SER } & $\begin{array}{c}\text { Pearson } \\
\text { Correlation }\end{array}$ & 0.190 & $0.218 *$ & $0.238 *$ & $0.338 * *$ \\
\hline & Sig. (2-tailed) & 0.087 & 0.049 & 0.031 & 0.002 \\
\hline \multirow[t]{2}{*}{ GLY } & $\begin{array}{c}\text { Pearson } \\
\text { Correlation }\end{array}$ & $0.355 * *$ & $0.363 * *$ & $0.398 * *$ & $0.468 * *$ \\
\hline & Sig. (2-tailed) & 0.001 & 0.001 & 0.000 & 0.000 \\
\hline \multirow[t]{2}{*}{ VAL } & $\begin{array}{c}\text { Pearson } \\
\text { Correlation }\end{array}$ & $0.229 *$ & $0.281 *$ & $0.329 * *$ & $0.457 * *$ \\
\hline & Sig. (2-tailed) & 0.038 & 0.010 & 0.003 & 0.000 \\
\hline \multirow[t]{2}{*}{ MET/CYT } & $\begin{array}{c}\text { Pearson } \\
\text { Correlation }\end{array}$ & -0.072 & -0.075 & -0.110 & 0.097 \\
\hline & Sig. (2-tailed) & 0.518 & 0.501 & 0.325 & 0.390 \\
\hline \multirow[t]{2}{*}{ XLE } & $\begin{array}{c}\text { Pearson } \\
\text { Correlation }\end{array}$ & 0.008 & 0.067 & -0.007 & 0.196 \\
\hline & Sig. (2-tailed) & 0.946 & 0.548 & 0.952 & 0.080 \\
\hline \multirow[t]{2}{*}{ TYR } & $\begin{array}{c}\text { Pearson } \\
\text { Correlation }\end{array}$ & -0.082 & -0.025 & -0.113 & 0.061 \\
\hline & Sig. (2-tailed) & 0.466 & 0.827 & 0.314 & 0.591 \\
\hline \multirow[t]{2}{*}{ LYS } & $\begin{array}{c}\text { Pearson } \\
\text { Correlation }\end{array}$ & 0.032 & 0.049 & 0.030 & 0.135 \\
\hline & Sig. (2-tailed) & 0.774 & 0.660 & 0.792 & 0.230 \\
\hline \multirow[t]{2}{*}{ HIS } & $\begin{array}{c}\text { Pearson } \\
\text { Correlation }\end{array}$ & $0.232 *$ & $0.224 *$ & $0.243 *$ & $0.287 * *$ \\
\hline & Sig. (2-tailed) & 0.036 & 0.043 & 0.028 & 0.009 \\
\hline \multirow[t]{2}{*}{ PHE } & $\begin{array}{c}\text { Pearson } \\
\text { Correlation } \\
\end{array}$ & 0.058 & 0.061 & 0.056 & 0.157 \\
\hline & Sig. (2-tailed) & 0.604 & 0.584 & 0.616 & 0.163 \\
\hline \multirow[t]{2}{*}{ ARG } & $\begin{array}{c}\text { Pearson } \\
\text { Correlation }\end{array}$ & 0.209 & $0.255 *$ & $0.324 * *$ & $0.419 * *$ \\
\hline & Sig. (2-tailed) & 0.059 & 0.021 & 0.003 & 0.000 \\
\hline
\end{tabular}


Table S4. MANOVA tests of between-subjects effects on the original $\delta^{13} \mathrm{C}$ dataset (uncorrected) using SEX as independent variable and $\delta^{13} \mathrm{C}$ values of 13 amino acids (11 variables) as dependent variables. There was a statistically significant difference between the $\delta^{13} \mathrm{C}$ values of Gly, Val and His of males and females. $n=82$ ( 25 males, 57 females), $\alpha=0.05$.

\begin{tabular}{c|c|c|c|c|c|c|c}
\hline \multicolumn{2}{c|}{ Source } & $\begin{array}{c}\text { Type III } \\
\text { Sum of } \\
\text { Squares }\end{array}$ & df & $\begin{array}{c}\text { Mean } \\
\text { Square }\end{array}$ & $\boldsymbol{F}$ & Sig. & $\begin{array}{c}\text { Partial } \\
\text { Eta } \\
\text { Squared }\end{array}$ \\
\hline \multirow{6}{*}{ Sex } & ASX & 2.451 & 1 & 2.451 & 1.422 & 0.237 & 0.017 \\
\cline { 2 - 9 } & SER & 8.459 & 1 & 8.459 & 3.010 & 0.087 & 0.036 \\
\cline { 2 - 9 } & GLY & 36.217 & 1 & 36.217 & $\mathbf{1 1 . 5 6 2}$ & $\mathbf{0 . 0 0 1}$ & $\mathbf{0 . 1 2 6}$ \\
\cline { 2 - 9 } & VAL & 9.390 & 1 & 9.390 & $\mathbf{4 . 4 3 8}$ & $\mathbf{0 . 0 3 8}$ & $\mathbf{0 . 0 5 3}$ \\
\cline { 2 - 9 } & MET_CYT & 0.488 & 1 & 0.488 & 0.422 & 0.518 & 0.005 \\
\cline { 2 - 9 } & XLE & 0.008 & 1 & 0.008 & 0.005 & 0.946 & 0.000 \\
\cline { 2 - 8 } & TYR & 1.043 & 1 & 1.043 & 0.537 & 0.466 & 0.007 \\
\cline { 2 - 8 } & LYS & 0.550 & 1 & 0.550 & 0.083 & 0.774 & 0.001 \\
\cline { 2 - 9 } & HIS & 58.321 & 1 & 58.321 & $\mathbf{4 . 5 4 1}$ & $\mathbf{0 . 0 3 6}$ & $\mathbf{0 . 0 5 4}$ \\
\cline { 2 - 9 } & PHE & 1.332 & 1 & 1.332 & 0.272 & 0.604 & 0.003 \\
\cline { 2 - 8 } & ARG & 7.324 & 1 & 7.324 & 3.658 & 0.059 & 0.044 \\
\hline
\end{tabular}


Table S5. MANOVA tests of between-subjects effects on the data corrected with individual bulk carbon measurements using SEX as independent variable and $\delta^{13} \mathrm{C}$ values of 13 amino acids (11 variables) as dependent variables. After the correction for diet, there was a statistically significant difference between the $\delta^{13} \mathrm{C}$ values of Ser, Gly, Val, His and Arg of males and females. Using a Bonferroni adjusted $\alpha=4.5 \times 10^{-3}$ ( $\alpha$ value/ number of dependent variables), the $\delta^{13} \mathrm{C}$ value of His was not significant anymore. $n=81$ ( 25 males, 56 females), $\alpha=0.05$.

\begin{tabular}{c|c|c|c|c|c|c|c}
\hline \multicolumn{2}{c}{ Source } & $\begin{array}{c}\text { Type III } \\
\text { Sum of } \\
\text { Squares }\end{array}$ & df & $\begin{array}{c}\text { Mean } \\
\text { Square }\end{array}$ & $\boldsymbol{F}$ & Sig. & $\begin{array}{c}\text { Partial } \\
\text { Eta } \\
\text { Squared }\end{array}$ \\
\hline \multirow{6}{*}{ Sex } & ASX & 0.043 & 1 & 0.043 & 0.036 & 0.850 & 0.000 \\
\cline { 2 - 8 } & SER & 15.713 & 1 & 15.713 & $\mathbf{1 0 . 1 6 7}$ & $\mathbf{0 . 0 0 2}$ & $\mathbf{0 . 1 1 4}$ \\
\cline { 2 - 9 } & GLY & 56.889 & 1 & 56.889 & $\mathbf{2 2 . 1 1 9}$ & $\begin{array}{c}\mathbf{1 . 0 7} \boldsymbol{x} \\
\mathbf{1 0}^{-5}\end{array}$ & $\mathbf{0 . 2 1 9}$ \\
\cline { 2 - 8 } & VAL & 22.643 & 1 & 22.643 & $\mathbf{2 0 . 8 7 3}$ & $\begin{array}{c}\mathbf{1 . 7 8} \boldsymbol{x} \\
\mathbf{1 0}-5\end{array}$ & $\mathbf{0 . 2 0 9}$ \\
\cline { 2 - 8 } & MET_CYT & 1.018 & 1 & 1.018 & 0.748 & 0.390 & 0.009 \\
\cline { 2 - 8 } & XLE & 3.191 & 1 & 3.191 & 3.143 & 0.080 & 0.038 \\
\cline { 2 - 8 } & TYR & 0.434 & 1 & 0.434 & 0.292 & 0.591 & 0.004 \\
\cline { 2 - 8 } & LYS & 8.542 & 1 & 8.542 & 1.463 & 0.230 & 0.018 \\
\cline { 2 - 8 } & HIS & 85.925 & 1 & 85.925 & $\mathbf{7 . 1 0 8}$ & $\mathbf{0 . 0 0 9}$ & $\mathbf{0 . 0 8 3}$ \\
\cline { 2 - 8 } & PHE & 9.713 & 1 & 9.713 & 1.987 & 0.163 & 0.025 \\
\cline { 2 - 8 } & ARG & 19.203 & 1 & 19.203 & $\mathbf{1 6 . 8 2 9}$ & $\mathbf{9 . 8 6} \boldsymbol{x}$ & $\mathbf{0 . 1 7 6}$ \\
\hline
\end{tabular}


Table S6. Descriptive statistics of the data corrected with individual bulk carbon measurements using SEX as independent variable and $\delta^{13} \mathrm{C}$ values of 13 amino acids (11 variables) as dependent variables. The difference in the mean scores for males and females was at most $2 \%$.

\begin{tabular}{|c|c|c|c|c|}
\hline $\mathbf{A A}$ & $\operatorname{Sex}$ & Mean & Std. Deviation & $n$ \\
\hline \multirow[t]{3}{*}{$\overline{\mathrm{SER}}$} & Male & -10.120 & 1.387 & 25 \\
\hline & Female & -9.166 & 1.175 & 56 \\
\hline & Total & -9.460 & 1.312 & 81 \\
\hline \multirow[t]{3}{*}{ GLY } & Male & -12.432 & 1.996 & 25 \\
\hline & Female & -10.617 & 1.399 & 56 \\
\hline & Total & -11.177 & 1.803 & 81 \\
\hline \multirow[t]{3}{*}{ VAL } & Male & -23.610 & 1.065 & 25 \\
\hline & Female & -22.465 & 1.031 & 56 \\
\hline & Total & -22.819 & 1.164 & 81 \\
\hline \multirow[t]{3}{*}{$\overline{\mathrm{HIS}}$} & Male & -12.321 & 3.104 & 25 \\
\hline & Female & -10.091 & 3.628 & 56 \\
\hline & Total & -10.779 & 3.607 & 81 \\
\hline \multirow[t]{3}{*}{$\overline{\mathrm{ARG}}$} & Male & -18.860 & .974 & 25 \\
\hline & Female & -17.806 & 1.107 & 56 \\
\hline & Total & -18.131 & 1.169 & 81 \\
\hline
\end{tabular}


Table S7. Linear discriminant analysis (classification) of 81 subjects ( 25 males, 56 females) according to SEX after data correction for diet. We used the $\delta^{13} \mathrm{C}$ values of Asx, Ser, Gly, Val, Met/Cyt, Xle, Tyr, Lys, His, Phe and Arg (11 variables, 13 amino acids) as variables. Subjects were correctly classified as males or females with approximately $78 \%$ accuracy after leave-oneout cross validation.

\begin{tabular}{|c|c|c|c|c|c|}
\hline & & \multirow{2}{*}{ Sex } & \multicolumn{2}{|c|}{ Predicted Group Membership } & \multirow{2}{*}{ Total } \\
\hline & & & Male & Female & \\
\hline \multirow{4}{*}{ Original } & \multirow{2}{*}{ Count } & 1 & 14 & 11 & 25 \\
\hline & & 2 & 4 & 52 & 56 \\
\hline & \multirow{2}{*}{$\%$} & 1 & 56.0 & 44.0 & 100.0 \\
\hline & & 2 & 7.1 & 92.9 & 100.0 \\
\hline \multirow{4}{*}{ Cross-validated $^{c}$} & \multirow{2}{*}{ Count } & 1 & 13 & 12 & 25 \\
\hline & & 2 & 6 & 50 & 56 \\
\hline & \multirow{2}{*}{$\%$} & 1 & 52.0 & 48.0 & 100.0 \\
\hline & & 2 & 10.7 & 89.3 & 100.0 \\
\hline
\end{tabular}

a. $81.5 \%$ of original grouped cases correctly classified.

b. $77.8 \%$ of cross-validated grouped cases correctly classified.

c. Cross validation is done only for those cases in the analysis. In cross validation, each case is classified by the functions derived from all cases other than that case. 
Table S8. Standardized canonical discriminant function coefficients using SEX as a discrimination factor. $\delta^{13} \mathrm{C}$ variables with large absolute coefficient values have a bigger impact on the separation of subject into sex groups and successful classification. The data was corrected for diet using individual bulk measurements prior to analysis.

Standardized Canonical Discriminant Function Coefficients

\begin{tabular}{c|c}
\hline AA & Function 1 \\
\hline SER & .230 \\
\hline GLY & .473 \\
\hline VAL & .380 \\
\hline HIS & .134 \\
\hline ARG & .240 \\
\hline
\end{tabular}


Table S9. MANOVA tests of between-subjects effects using SEX as independent variable and the quantities of 7 amino acids as dependent variables. Using a Bonferroni adjusted $\alpha=8.3 \times 10^{-3}$ $(\alpha=0.05 /$ number of dependent variables), Ser and Arg were not significant anymore. The subscript $q$ was added to each variable to differentiate them from the names used with carbon isotopes. $n=82$ ( 25 males, 57 females).

\begin{tabular}{|c|c|c|c|c|c|c|c|}
\hline Source & $\begin{array}{c}\text { Dependent } \\
\text { Variable }\end{array}$ & $\begin{array}{l}\text { Type III } \\
\text { Sum of } \\
\text { Squares }\end{array}$ & df & $\begin{array}{c}\text { Mean } \\
\text { Square }\end{array}$ & $F$ & Sig. & $\begin{array}{c}\text { Partial Eta } \\
\text { Squared }\end{array}$ \\
\hline \multirow{6}{*}{ Sex } & $\mathrm{SER}_{\mathrm{q}}$ & .361 & 1 & .361 & 5.044 & .027 & .059 \\
\hline & $\mathbf{V A L}_{\mathrm{q}}$ & 1.729 & 1 & 1.729 & 80.31 & $\begin{array}{c}1.04 x \\
10^{-13}\end{array}$ & .501 \\
\hline & $\overline{X_{L E}}$ & 1.056 & 1 & 1.056 & 24.88 & $3 \times 10^{-6}$ & .237 \\
\hline & $\overline{T_{Y} R_{q}}$ & .254 & 1 & .254 & 19.82 & $2.7 \times 10^{-5}$ & .199 \\
\hline & $\mathbf{L Y S}_{\mathrm{q}}$ & .025 & 1 & .025 & 8.91 & .004 & .100 \\
\hline & $\overline{\mathrm{ARG}_{\mathrm{q}}}$ & .045 & 1 & .049 & 4.503 & .037 & .053 \\
\hline
\end{tabular}


Table S10. Linear discriminant analysis (classification) of 82 subjects ( 25 males, 57 females) according to SEX. We used the quantities of Asx, Ser, Gly, Val, Xle, Tyr, Lys, His, Phe and Arg (10 variables, 11 amino acids) as variables. Subjects were correctly classified as males or females with approximately $94 \%$ accuracy after leave-one-out cross validation.

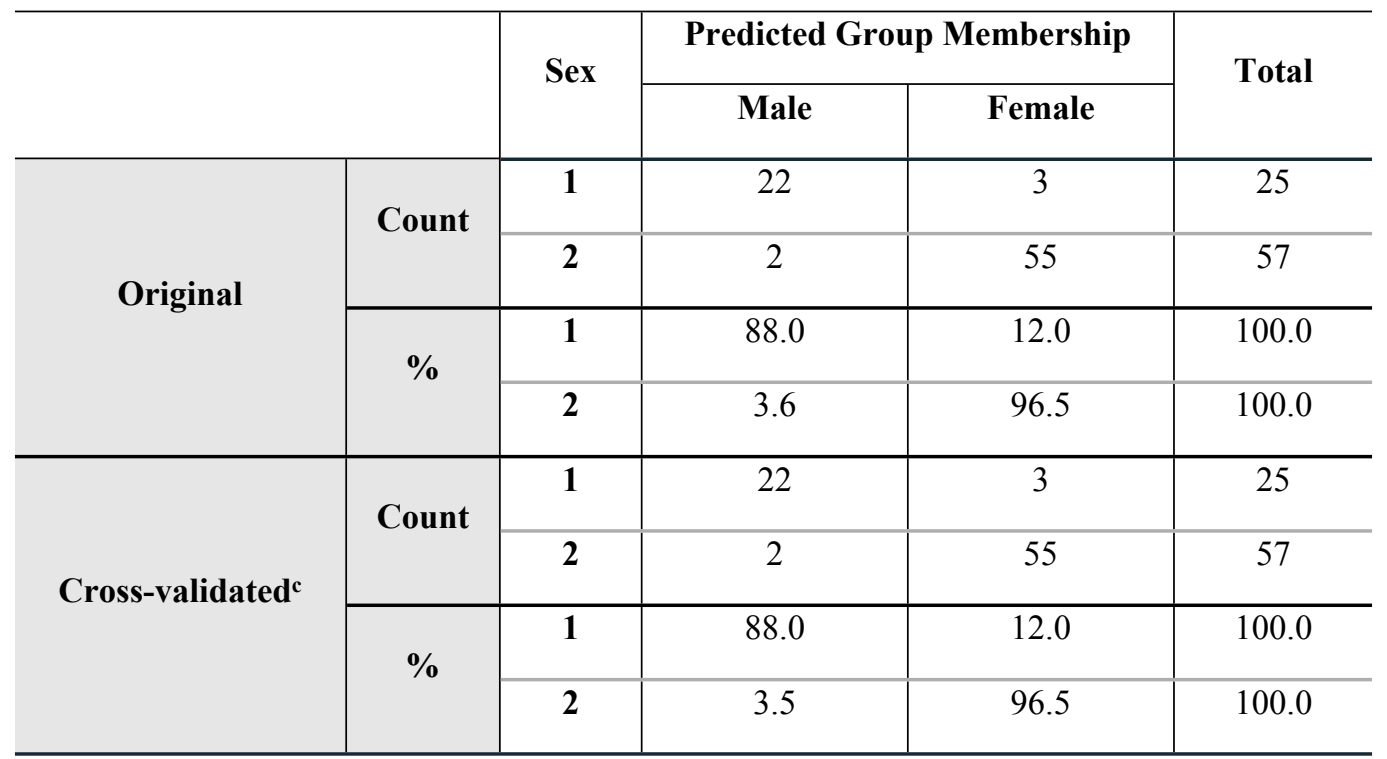

a. $93.9 \%$ of original grouped cases correctly classified.

b. $93.9 \%$ of cross-validated grouped cases correctly classified.

c. Cross validation is done only for those cases in the analysis. In cross validation, each case is classified by the functions derived from all cases other than that case. 
Table S11. Standardized canonical discriminant function coefficients using SEX as a discrimination factor. Quantities of AA with large absolute coefficient values have a bigger impact on the separation of subject into sex groups and successful classification.

Standardized Canonical Discriminant

Function Coefficients

\begin{tabular}{c|c}
\hline $\mathbf{A A}$ & Function 1 \\
\hline $\mathrm{VAL}_{\mathrm{q}}$ & 1.374 \\
$\mathrm{XLE}_{\mathrm{q}}$ & -.626 \\
\hline $\mathrm{TYR}_{\mathrm{q}}$ & .009 \\
\hline $\mathrm{LYS}_{\mathrm{q}}$ & -.396 \\
\hline
\end{tabular}


Table S12. Person product-moment correlation coefficient for AGE factor vs. $\delta^{13} \mathrm{C}$ values of 13 amino acids (11 variables). The strength of correlation and significance slightly increased after corrections for diet. There were no significant correlations when age was separated in groups (results not shown). * indicates correlation was significant at the 0.05 level (2-tailed), ** correlation was significant at the 0.01 level (2-tailed). $n=82$ for original data and all diet corrections, except bulk diet correction $(n=81)$.

\begin{tabular}{|c|c|c|c|c|c|c|c|}
\hline $\begin{array}{l}\text { Amino } \\
\text { acid }\end{array}$ & $\begin{array}{l}\text { Correlation } \\
\text { coefficient }\end{array}$ & $\begin{array}{c}\text { Original } \\
\delta^{13} \mathrm{C} \\
\text { dataset }\end{array}$ & $\begin{array}{c}\text { Diet } \\
\text { correction } \\
\text { for meat } \\
\text { intake } \\
\end{array}$ & $\begin{array}{l}\text { Weighted } \\
\text { diet } \\
\text { correction }\end{array}$ & $\begin{array}{l}\text { Bulk diet } \\
\text { correction }\end{array}$ & $\begin{array}{l}\text { Sex correction } \\
\text { after weighted } \\
\text { diet correction }\end{array}$ & $\begin{array}{c}\text { Sex } \\
\text { correction } \\
\text { after bulk diet } \\
\text { correction }\end{array}$ \\
\hline & & Age & Age & Age & Age & Age & Age \\
\hline \multirow[t]{2}{*}{ ASX } & $\begin{array}{c}\text { Pearson } \\
\text { Correlation }\end{array}$ & -0.091 & -0.092 & -0.18 & -0.069 & -0.184 & -0.068 \\
\hline & Sig. (2-tailed) & 0.416 & 0.41 & 0.105 & 0.542 & 0.098 & 0.544 \\
\hline \multirow[t]{2}{*}{ SER } & $\begin{array}{c}\text { Pearson } \\
\text { Correlation }\end{array}$ & 0.012 & 0.013 & -0.051 & -0.003 & -0.052 & 0.004 \\
\hline & Sig. (2-tailed) & 0.914 & 0.905 & 0.651 & 0.981 & 0.644 & 0.969 \\
\hline \multirow[t]{2}{*}{ GLY } & $\begin{array}{c}\text { Pearson } \\
\text { Correlation }\end{array}$ & -0.098 & -0.115 & -0.152 & -0.135 & -0.165 & -0.142 \\
\hline & Sig. (2-tailed) & 0.382 & 0.305 & 0.174 & 0.23 & 0.139 & 0.206 \\
\hline \multirow[t]{2}{*}{ VAL } & $\begin{array}{c}\text { Pearson } \\
\text { Correlation }\end{array}$ & -0.011 & -0.015 & -0.082 & -0.001 & -0.086 & 0.009 \\
\hline & Sig. (2-tailed) & 0.924 & 0.892 & 0.466 & 0.994 & 0.443 & 0.934 \\
\hline \multirow[t]{2}{*}{ MET/CYT } & $\begin{array}{c}\text { Pearson } \\
\text { Correlation }\end{array}$ & 0.021 & 0.019 & -0.052 & 0.041 & -0.052 & 0.043 \\
\hline & Sig. (2-tailed) & 0.854 & 0.865 & 0.643 & 0.719 & 0.641 & 0.705 \\
\hline \multirow[t]{2}{*}{ XLE } & $\begin{array}{c}\text { Pearson } \\
\text { Correlation }\end{array}$ & 0.171 & $0.219^{*}$ & $0.245^{*}$ & $0.242 *$ & $0.245 *$ & $0.251 *$ \\
\hline & Sig. (2-tailed) & 0.125 & 0.048 & 0.026 & 0.029 & 0.026 & 0.024 \\
\hline \multirow[t]{2}{*}{ TYR } & $\begin{array}{c}\text { Pearson } \\
\text { Correlation }\end{array}$ & 0.082 & 0.109 & 0.043 & 0.109 & 0.043 & 0.111 \\
\hline & Sig. (2-tailed) & 0.464 & 0.328 & 0.701 & 0.332 & 0.7 & 0.326 \\
\hline \multirow[t]{2}{*}{ LYS } & $\begin{array}{c}\text { Pearson } \\
\text { Correlation }\end{array}$ & $-0.256^{*}$ & $-0.267^{*}$ & $-0.312 * *$ & -0.197 & $-0.312 * *$ & -0.197 \\
\hline & Sig. (2-tailed) & 0.02 & 0.015 & 0.004 & 0.077 & 0.004 & 0.079 \\
\hline \multirow[t]{2}{*}{ HIS } & $\begin{array}{c}\text { Pearson } \\
\text { Correlation }\end{array}$ & 0.076 & 0.072 & 0.062 & 0.076 & 0.064 & 0.086 \\
\hline & Sig. (2-tailed) & 0.5 & 0.52 & 0.582 & 0.499 & 0.568 & 0.448 \\
\hline \multirow[t]{2}{*}{ PHE } & $\begin{array}{c}\text { Pearson } \\
\text { Correlation }\end{array}$ & 0.104 & 0.104 & 0.081 & 0.161 & 0.081 & 0.166 \\
\hline & Sig. (2-tailed) & 0.352 & 0.35 & 0.472 & 0.152 & 0.47 & 0.139 \\
\hline \multirow[t]{2}{*}{ ARG } & $\begin{array}{c}\text { Pearson } \\
\text { Correlation } \\
\end{array}$ & 0.023 & 0.025 & -0.036 & 0.038 & -0.037 & 0.051 \\
\hline & Sig. (2-tailed) & 0.834 & 0.821 & 0.75 & 0.74 & 0.74 & 0.654 \\
\hline
\end{tabular}


Table S13. Independent sample $t$-tests (Student's $t$-test) comparing the carbon and nitrogen bulk isotope values of females who did different different hair treatments. The one subject who did chemical straithening was not included in this analysis. However, its value $\left(\delta^{13} \mathrm{C}=-18.682, \delta^{15} \mathrm{~N}\right.$ $=9.863$ ) was not vastly different from the other treatments mean. $n=25$, two-sample assuming unequal variance, $\alpha=0.05$.

\begin{tabular}{|c|c|c|}
\hline & Average TRUE $\delta^{13} C$ - Bleach and coloring & Average TRUE $\delta^{13} \mathrm{C}$ - Coloring \\
\hline Mean & -18.329 & -18.998 \\
\hline Variance & 0.308 & 2.582 \\
\hline Observations & 5 & 20 \\
\hline Hypothesized Mean Difference & 0 & \\
\hline $\mathrm{df}$ & 20 & \\
\hline$t$ Stat & 1.531 & \\
\hline$P(T<=t)$ one-tail & 0.071 & \\
\hline$t$ Critical one-tail & 1.725 & \\
\hline$P(T<=t)$ two-tail & 0.141 & \\
\hline \multirow[t]{2}{*}{$t$ Critical two-tail } & 2.086 & \\
\hline & Average TRUE $\delta^{15} N$ - Bleach and coloring & Average TRUE $\delta^{15} N$ - Coloring \\
\hline Mean & 9.418 & 9.456 \\
\hline Variance & 0.072 & 0.901 \\
\hline Observations & 5 & 20 \\
\hline Hypothesized Mean Difference & 0 & \\
\hline $\mathrm{df}$ & 22 & \\
\hline$t$ Stat & -0.157 & \\
\hline$P(\mathrm{~T}<=t)$ one-tail & 0.438 & \\
\hline$t$ Critical one-tail & 1.717 & \\
\hline$P(T<=t)$ two-tail & 0.876 & \\
\hline$t$ Critical two-tail & 2.074 & \\
\hline
\end{tabular}


Table S14. Independent sample t-tests (Student's $t$-test) comparing the carbon and nitrogen bulk isotope values of females who did any of the hair treatments vs. the ones who did not. $n=71$, two-sample assuming unequal variance, $\alpha=0.05$.

\begin{tabular}{|c|c|c|}
\hline & Average TRUE $\delta^{13} C$ - no hair treatment & Average TRUE $\delta^{13} C$ - with hair treatment \\
\hline Mean & -18.823 & -18.857 \\
\hline Variance & 0.646 & 2.085 \\
\hline Observations & 45 & 26 \\
\hline Hypothesized Mean Difference & 0 & \\
\hline $\mathrm{df}$ & 34 & \\
\hline$t$ Stat & 0.111 & \\
\hline$P(\mathrm{~T}<=t)$ one-tail & 0.456 & \\
\hline$t$ Critical one-tail & 1.691 & \\
\hline$P(\mathrm{~T}<=t)$ two-tail & 0.912 & \\
\hline \multirow[t]{2}{*}{$t$ Critical two-tail } & 2.032 & \\
\hline & Average TRUE $\delta^{15} N$ - no hair treatment & Average TRUE $\delta^{15} N$ - with hair treatment \\
\hline Mean & 9.715 & 9.465 \\
\hline Variance & 0.240 & 0.703 \\
\hline Observations & 45 & 26 \\
\hline Hypothesized Mean Difference & 0 & \\
\hline $\mathrm{df}$ & 35 & \\
\hline t Stat & 1.392 & \\
\hline$P(\mathrm{~T}<=t)$ one-tail & 0.086 & \\
\hline$t$ Critical one-tail & 1.690 & \\
\hline$P(\mathrm{~T}<=t)$ two-tail & 0.173 & \\
\hline$t$ Critical two-tail & 2.030 & \\
\hline
\end{tabular}


Table S15. Independent sample t-tests (Student's $t$-test) comparing the $\delta^{13} \mathrm{C}$ values of females who did any of the hair treatments vs. those with untreated hair. $n=57$, two-sample assuming unequal variance, $\alpha=0.05$.

\begin{tabular}{l|c|c}
\hline Null hypothesis & $t$ & Sig. \\
\hline $\begin{array}{l}\text { The distribution of } \delta^{13} \mathrm{C} \text { ASX is the same across } \\
\text { categories of Hair treatment }\end{array}$ & -0.147 & 0.884 \\
\hline $\begin{array}{l}\text { The distribution of } \delta^{13} \mathrm{C} \text { SER is the same across } \\
\text { categories of Hair treatment }\end{array}$ & 0.044 & 0.966 \\
\hline $\begin{array}{l}\text { The distribution of } \delta^{13} \mathrm{C} \text { GLY is the same across } \\
\text { categories of Hair treatment }\end{array}$ & 1.400 & 0.172 \\
\hline $\begin{array}{l}\text { The distribution of } \delta^{13} \mathrm{C} \text { VAL is the same across } \\
\text { categories of Hair treatment }\end{array}$ & 1.091 & 0.284 \\
\hline $\begin{array}{l}\text { The distribution of } \delta^{13} \mathrm{C} \text { MET/ CYT is the same } \\
\text { across categories of Hair treatment }\end{array}$ & 0.519 & 0.607 \\
\hline $\begin{array}{l}\text { The distribution of } \delta^{13} \mathrm{C} \text { XLE is the same across } \\
\text { categories of Hair treatment }\end{array}$ & 0.811 & 0.426 \\
\hline $\begin{array}{l}\text { The distribution of } \delta^{13} \mathrm{C} \text { TYR is the same across } \\
\text { categories of Hair treatment }\end{array}$ & 1.436 & 0.161 \\
\hline $\begin{array}{l}\text { The distribution of } \delta^{13} \mathrm{C} \text { LYS is the same across } \\
\text { categories of Hair treatment }\end{array}$ & 0.297 & 0.769 \\
\hline $\begin{array}{l}\text { The distribution of } \delta^{13} \mathrm{C} \text { HIS is the same across } \\
\text { categories of Hair treatment }\end{array}$ & 1.670 & 0.102 \\
\hline $\begin{array}{l}\text { The distribution of } \delta^{13} \mathrm{C} \text { PHE is the same across } \\
\text { categories of Hair treatment }\end{array}$ & 1.716 & 0.094 \\
\hline $\begin{array}{l}\text { The distribution of } \delta^{13} \mathrm{C} \text { ARG is the same across } \\
\text { categories of Hair treatment }\end{array}$ & 1.486 & 0.148 \\
\hline
\end{tabular}


Table S16. Independent sample $t$-tests (Student's $t$-test) comparing the quantities of amino acids in females who did any of the hair treatments vs. those with untreated hair. $n=57$, two-sample assuming unequal variance, $\alpha=0.05$.

\begin{tabular}{l|c|c}
\hline Null hypothesis & $\boldsymbol{t}$ & Sig. \\
\hline $\begin{array}{l}\text { The distribution of } \mathrm{ASX}_{\mathrm{q}} \text { is the same across } \\
\text { categories of Hair treatment }\end{array}$ & 0.414 & 0.681 \\
\hline $\begin{array}{l}\text { The distribution of } \mathrm{SER}_{\mathrm{q}} \text { is the same across } \\
\text { categories of Hair treatment }\end{array}$ & -1.122 & 0.268 \\
\hline $\begin{array}{l}\text { The distribution of GLY } \mathbf{G}_{\mathrm{q}} \text { is the same across } \\
\text { categories of Hair treatment }\end{array}$ & $\mathbf{- 2 . 2 5 6}$ & $\mathbf{0 . 0 2 8}$ \\
\hline $\begin{array}{l}\text { The distribution of } \mathrm{VAL}_{\mathrm{q}} \text { is the same across } \\
\text { categories of Hair treatment }\end{array}$ & -0.635 & 0.529 \\
\hline $\begin{array}{l}\text { The distribution of } \mathrm{XLE}_{\mathrm{q}} \text { is the same across } \\
\text { categories of Hair treatment }\end{array}$ & 0.987 & 0.328 \\
\hline $\begin{array}{l}\text { The distribution of } \mathrm{TYR}_{\mathrm{q}} \text { is the same across } \\
\text { categories of Hair treatment }\end{array}$ & -0.135 & 0.893 \\
\hline $\begin{array}{l}\text { The distribution of } \mathrm{LYS}_{\mathrm{q}} \text { is the same across } \\
\text { categories of Hair treatment }\end{array}$ & -0.732 & 0.469 \\
\hline $\begin{array}{l}\text { The distribution of } \mathrm{HIS}_{\mathrm{q}} \text { is the same across } \\
\text { categories of Hair treatment }\end{array}$ & -0.413 & 0.682 \\
\hline $\begin{array}{l}\text { The distribution of } \mathrm{PHE}_{\mathrm{q}} \text { is the same across } \\
\text { categories of Hair treatment }\end{array}$ & -1.170 & 0.247 \\
\hline $\begin{array}{l}\text { The distribution of } \mathrm{ARG}_{\mathrm{q}} \text { is the same across } \\
\text { categories of Hair treatment }\end{array}$ & -0.488 & 0.628 \\
\hline
\end{tabular}


1. Fuller, B. T.; Fuller, J. L.; Sage, N. E.; Harris, D. A.; O'Connell, T. C.; Hedges, R. E., Nitrogen balance and $\delta^{15} \mathrm{~N}$ : why you're not what you eat during pregnancy. Rapid Commun. Mass Spectrom. 2004, 18 (23), 2889-96.

2. $\quad$ Fuller, B. T.; Fuller, J. L.; Sage, N. E.; Harris, D. A.; O'Connell, T. C.; Hedges, R. E., Nitrogen balance and $\delta^{15} \mathrm{~N}$ : why you're not what you eat during nutritional stress. Rapid Commun. Mass Spectrom. 2005, 19 (18), 2497-506.

3. Petzke, K. J.; Boeing, H.; Klaus, S.; Metges, C. C., Carbon and nitrogen stable isotopic composition of hair protein and amino acids can be used as biomarkers for animal-derived dietary protein intake in humans. J. Nutr. 2005, 135 (6), 1515-1520.

4. An, Y.; Schwartz, Z.; Jackson, G. P., $\delta^{13} \mathrm{C}$ analysis of amino acids in human hair using trimethylsilyl derivatives and gas chromatography/combustion/isotope ratio mass spectrometry. Rapid Commun. Mass Spectrom. 2013, 27 (13), 1481-9.

5. Jackson, G. P.; An, Y.; Konstantynova, K. I.; Rashaid, A. H. B., Biometrics from the carbon isotope ratio analysis of amino acids in human hair. Sci. Justice 2015, 55, 43-50.

6. Meier-Augenstein, W.; Fraser, I., Forensic isotope analysis leads to identification of a mutilated murder victim. Sci. Justice 2008, 48 (3), 153-9.

7. Carter, J. F.; Fry, B., Ensuring the reliability of stable isotope ratio data-beyond the principle of identical treatment. Anal. Bioanal. Chem. 2013, 405 (9), 2799-814.

8. Coplen, T. B., Guidelines and recommended terms for expression of stable-isotope-ratio and gas-ratio measurement results. Rapid Commun. Mass Spectrom. 2011, 25, 2538-2560.

9. $\quad$ Dunn, P. J. H.; Carter, J. F., Good Practice Guide for Isotope Ratio Mass Spectrometry. 2nd ed.; FIRMS: 2018; p 84.

10. Rashaid, A. H. B.; Jackson, G. P.; Harrington, P. B., Quantitation of Amino Acids in Human Hair by Trimethylsilyl Derivatization Gas Chromatography-Mass Spectrometry. Enliven: Bio analytical Techniques 2014, 1 (1), 1-12.

11. Rayner, C. J., Protein Hydrolysis of Animal Feeds for Amino Acid Content. J. Agric. Food Chem. 1985, 33, 722-725.

12. Fountoulakis, M.; Lahm, H.-W., Hydrolysis and amino acid composition analysis of proteins. J. Chromatogr. A 1988, 826, 109-134.

13. Roberts, P.; Jones, D. L., Critical evaluation of methods for determining total protein in soil solution. Soil Biol. Biochem. 2008, 40 (6), 1485-1495.

14. Howland, M. R.; Corr, L. T.; Young, S. M. M.; Jones, V.; Jim, S.; Van Der Merwe, N. J.; Mitchell, A. D.; Evershed, R. P., Expression of the dietary isotope signal in the compoundspecific d13C values of pig bone lipids and amino acids. International Journal of Osteoarchaeology 2003, 13 (1-2), 54-65.

15. Matos, M. P. V.; Konstantynova, K. I.; Mohr, R. M.; Jackson, G. P., Analysis of the ${ }^{13}$ C isotope ratios of amino acids in the larvae, pupae and adult stages of Calliphora vicina blow flies and their carrion food sources. Anal. Bioanal. Chem. 2018, 410 (30), 7943-7954.

16. Jim, S.; Jones, V.; Copley, M. S.; Ambrose, S. H.; Evershed, R. P., Effects of hydrolysis on the delta13C values of individual amino acids derived from polypeptides and proteins. Rapid Commun. Mass Spectrom. 2003, 17 (20), 2283-9.

17. Enggrob, K. L.; Larsen, T.; Larsen, M.; Elsgaard, L.; Rasmussen, J., The influence of hydrolysis and derivatization on the determination of amino acid content and isotopic ratios in dual-labeled $\left({ }^{13} \mathrm{C},{ }^{15} \mathrm{~N}\right)$ white clover. Rapid Commun. Mass Spectrom. 2019, 33 (1), 21-30.

18. McCullagh, J. S., Mixed-mode chromatography/isotope ratio mass spectrometry. Rapid Commun. Mass Spectrom. 2010, 24 (5), 483-94. 
19. Tabachnick, B. G.; Fidell, L. S., Using multivariate statistics. 6th ed.; Pearson Education: Boston, 2013; p 983.

20. Cohen, J., Statistical power analysis for the behavioral sciences. 2nd ed.; Lawrence Erlbaum Associates: Hillsdale, N.J, 1988; p 567.

21. Baba, N.; Nakayama, Y.; Nozaki, F.; Tamura, T., Denaturation and release of amino acids in hairs treated with cold-waving lotions, hair-dyes, hair-bleaching solutions and depilatories. J Hyg Chem 1973, 19 (2), 47-52.

22. O'Connell, T. C.; Hedges, R. E. M., Investigations into the effect of diet on modern human hair isotopic values. Am. J. Phys. Anthropol. 1999, 108 (4), 409-425.

23. Robbins, C. R., Chemical composition of different hair types. In Chemical and physical behavior of human hair, Springer-Verlag Berlin Heidelberg: 2012; 724.

24. Nogueira, A. C.; Dicelio, L. E.; Joekes, I., About photo-damage of human hair. Photochem Photobiol Sci 2006, 5 (2), 165-9.

25. Rashaid, A. H. B.; Harrington, P. B.; Jackson, G. P., Amino acid composition of human scalp hair as a biometric classifier and investigative lead. Analytical Methods 2015, 7 (5), 17071718 . 